\title{
Physicochemical Properties of Wheat Flour Dough Modified by Microbial Transglutaminase
}

\author{
C.-S. TSENG AND H.-M. LAI
}

\begin{abstract}
In this study, microbial transglutaminase (MTGase) was employed to modify viscoelasticity of wheat flour dough. Three flours, namely In-, Mid-, and Out-flour derived from different parts of wheat kernel, were used. When adding 16 ppm MTGase, the maximum resistance to extension ( $\left.R_{\max }\right)$ of In-(58\%), Mid- $(56 \%)$, and Outflour(52\%) doughs, prepared at specific water levels indicated in parentheses, is increased by $51 \%, 35 \%$, and $77 \%$, respectively. The extensibility $(\mathrm{E})$ of these 3 doughs is reduced by $16 \%, 11 \%$, and $6 \%$; the stickiness is also lowered by $12 \%, 5 \%$, and $22 \%$, respectively. SDS-PAGE analysis indicates that crosslinks occur within wheat gluten of MTGasetreated dough.

Keywords: transglutaminase, flour dough, viscoelasticity, stickiness, SDS-PAGE
\end{abstract}

\section{Introduction}

$\mathrm{E}$ NZYMATIC PROTEIN MODIFICATIONS HAVE BEEN REPORTED IN food processing industries. Various enzymes are used to meet different needs such as improving texture, flavor, or nutritional values, and simplifying processing steps (Singh 1991). Microbial transglutaminase (MTGase, EC 2.3.2.13), one of the enzymes widely used for protein modification in recent years due to its lower cost than mammalian TGase, is produced mostly from Streptoverticulum spp. (Seguro and others 1996). It is an extracellular enzyme with a remarkable characteristic of $\mathrm{Ca}^{2+}$-independent catalytic property (Ando and others 1989; Seguro and others 1996). The MTGase catalyzes the formation of inter- and intra-molecular $\varepsilon$ - $(\gamma$ glutamyl)lysine crosslinks (G-L bonds) in several food proteins such as soy proteins, milk proteins, egg proteins, and wheat proteins (Sakamoto and others 1994; Færgemand and Qvist 1997; Færgemand and others 1997; Kuraishi and others 1997; Soeda and others 1999). Food containing proteinaceous material was treated with transglutaminase and an oxidoreductase (European Patent EP 0963704 A2.1 1999; Soeda and others 1999; Imm and others 2000) The polymerization and gelation of food proteins with MTGase may affect qualities of many foods by modifying its physicochemical properties, including viscoelasticity, gelation, emulsification, and foaming (Færgemand and others 1998; Larré and others 2000).

Gliadin and glutenin are 2 major components of gluten in wheat flour dough that dominate viscoelasticity. The properties of gluten are dependent on wheat variety and growth conditions, and milling performance (Dube and others 1987; Chakraborty and Khan 1988; Posner and Hibbs 1997; Prabhasankar and others 2000). MacMasters and others (1971) reported nonuniform distribution of components within the wheat kernel, giving rise to variation in composition and functional characteristics of flour streams obtained in roller flour mills. Amino acid analyses of different sections of wheat kernel suggest that there are different distributions of protein classes throughout the wheat kernel (Jensen and Martens 1983). The proportion of basic amino acids increases and the nitrogen content decreases from the outside to- ward the center of the endosperm. The subaleurone cells are high in proteins and mainly salt-soluble proteins, while the salt-insoluble proteins, including gliadin and glutenin, are the major endosperm proteins. In general, the flour derived from the outer layer of wheat kernels is usually discarded due to its low content of gluten, high enzymatic activity, and dark color. The modifications of wheat flour proteins, especially for the flour containing poor properties of gliadins and glutenins, by physical, chemical, or enzymatic methods are therefore necessary in practical operations (Jones and others 1959; Stauffer 1990; Sproessler 1993). In recent years, MTGase has been reported as a potential enzyme that can be used in wheat flour for improving the dough properties and the quality of final products. MTGase-modified products reported include noodles and pasta (Sakamoto and others 1996), bread (Ashikawa and others 1990; Gerrard and others 1998), and pastry (Gerrard and others 2000). The effects of MTGase on the dough properties include improvement in extensibility, stickiness, water holding capacity, and consequently the qualities of cooking or baking goods. These are mainly attributed to the formation of $\varepsilon$-( $\gamma$-glutamyl)lysine crosslinks (G-L bonds) of gluten thus strengthening gluten network. Hypoallergenic wheat flour or soy protein, which is treated with MTGase to mask the allergenic structure that may be an epitope structure of wheat prolamin or soybean trypsin inhibitor, has been reported (Wantanabe and others 1994; Babiker and others 1998).

Since only high-quality flours, which are mainly derived from the central part of hard wheat kernels, are used for breads or noodle-making in Taiwan, the utilization of lowquality flours, which are mainly derived from the outer layer of hard wheat kernels, is limited. To increase the utilization of low-quality wheat flours, modifying flour properties by treating with functional additives is usually a method to be considered. However, the effects modifying flour properties may be various due to nonuniform distribution of compositions of wheat kernel. Therefore, the major purpose of this study is to investigate the modification effects of MTGasetreated wheat flour dough prepared from 3 different flours that are collected from selected flour streams. 
Table 1-Basic composition of In-, Mid- and Out-flours ${ }^{1}$

\begin{tabular}{|c|c|c|c|}
\hline \multirow[b]{2}{*}{ Composition } & \multicolumn{3}{|c|}{ Flour $(\%)^{2}$} \\
\hline & In- & Mid- & Out- \\
\hline Moisture & 12.95 & 12.87 & 12.97 \\
\hline Crude protein ${ }^{3}$ & 11.38 & 15.56 & 16.89 \\
\hline \multicolumn{4}{|l|}{ Gluten } \\
\hline Wet gluten & 35.48 & 59.31 & 62.48 \\
\hline Dry gluten & 14.69 & 24.34 & 27.36 \\
\hline Ash & 0.42 & 0.66 & 0.85 \\
\hline
\end{tabular}

1 Three replicates were done and the means were given. The CV of the measurement is less than $3 \%$.

2 On dry weight basis except the moisture content.

3 Protein content has been calculated as nitrogen $\times 5.7$.

\section{Materials and Methods}

\section{Materials}

Three flours with different compositions and rheological properties, obtained by a stream-splitting method in practical flour milling of dark northern spring wheat provided by a local flour mill (Taichung, Taiwan) were used in this study. The 3 flours are named In-, Mid-, or Out-flour, mainly according to the location of the wheat kernel from where the flour was derived. In-flour is mainly from C1A flour streams and Mid-flour is mainly from Divid1 flour streams, while Out-flour is mainly from $4 \mathrm{Bk}$ flour streams. The proximate composition of flour was analyzed according to AACC methods of 44-15A, 46-12 and 08-01 to determine the content of moisture, crude protein, and ash (AACC 1995). The physical tests of flour dough, which was prepared by farinography, were carried out by extensigraph according to AACC method 54-10 (AACC 1995). The results were compared to those from a texture analyzer. Gluten was obtained by the handwashing method according to AACC method 38-10.

The $\mathrm{Ca}^{2+}{ }^{2+}$ independent microbial transglutaminase (MTGase) containing $0.2 \%$ active enzyme and $99.8 \%$ starch (manufacturing specification) was provided by Ajinomoto Co., Inc. (Tokyo, Japan). The activity of MTGase was measured according to the method of Folk and Cole (1966). One unit (U) of enzyme activity is defined as the formation of 1 mmole of hydroxamic acid per min at $\mathrm{pH} 6.0$ and $37^{\circ} \mathrm{CJ}$. The activity of MTGase is $42 \mathrm{U} / \mathrm{mg}$ powder and the concentrations of MTGase used in this study are 8 or $16 \mathrm{ppm} .21 \mathrm{U} / \mathrm{g}$ flour is $1 \mathrm{ppm}$.

The L-ascorbic acid, used as an oxidant, was purchased from Nutritional Biochemicals Co. (Cleveland, Ohio, U.S.A.), and was added to the dough for comparison.

\section{Dough preparation}

$400 \mathrm{~g}$ of flour with or without MTGase or L-ascorbic acid was mixed with the desired amount of water, which depended on the flour properties, by using a KitchenAid desktop mixer (model KSMC50, KitchenAid, Denver, Colo., U.S.A.). Different water contents (on flour basis), 50 to $58 \%$ for Inflour, 50 to $56 \%$ for Mid-flour, and 46 to $52 \%$ for Out-flour, respectively, were applied according to the handling properties of each dough. The dough should not be too sticky to make-up or too dry to form a dough with a smooth surface. The dough was prepared by mixing the flour and water for 15 min on speed 2.

\section{Textural analyses of dough and gluten}

A texture analyzer with $25 \mathrm{~kg}$ cell load (model TA-XT2 $i$, Stable Micro Systems, Surrey, U.K.) with Kieffer dough and gluten extensibility rig (A/KIE) probe was used to measure the extensibility of dough and gluten because of the small amount of sample $(<20 \mathrm{~g})$ used. The method of Kieffer and Stein (1999) was adopted with some modifications. Dough was pressed into stripes using a Teflon mold and wrapped with double PP plastic bags. It was then allowed to stand for $30 \mathrm{~min}$ at room temperature $\left(25 \pm 3{ }^{\circ} \mathrm{C}\right)$ before measurements. Testing speed for the measurements was $3.3 \mathrm{~mm} / \mathrm{sec}$. The SMS/Chen-Hoseney dough stickiness rig (A/DCS) was used to measure dough stickiness with some modifications on Chen and Hoseney's method (1995). The modifications included $0.5 \mathrm{~mm} / \mathrm{sec}$ of compression speed and $60 \mathrm{~g}$ of compression force. The data were recorded with bundled Texture Expert software (version 1.22, Stable Micro Systems 1999). Three doughs were prepared for each measured variable and at least 15 stripes were measured for each prepared dough. Experimental data were analyzed statistically by 1-way ANOVA using Microsoft Excel (version 9.0). Differences among the means within the same flour were significant for treatments, using Duncan's new multiple range test $(p<0.05)$.

\section{SDS-polyacrylamide gel electrophoresis}

In order to investigate the polymerization effect of MTGase on the gluten of dough, $50 \mathrm{mg}$ of wet gluten obtained by the hand-washing method were suspended in eppendorf with $0.5 \mathrm{~mL}$ of $0.1 \mathrm{M}$ Tris- $\mathrm{HCl}(\mathrm{pH} 7.5)$ that contained 40 $\mathrm{ppm}$ of MTGase. The higher enzyme concentration chosen for SDS-PAGE than that used in the investigation of viscoelasticity of wheat dough described above was employed to observe a significant polymerization reaction of MTGase. Reaction was terminated by adding $0.5 \mathrm{~mL}$ of 2 -fold SDSsample buffer (containing 3\% Tris, $4 \%$ SDS, 4 mM EDTA.2Na, and $10 \% 2$-mercaptoethanol), followed by heating in boiling water for $10 \mathrm{~min}$. The reaction mixture was then centrifuged for 3 min under $8000 \times g$. Fifteen $\mathrm{mL}$ of resulting supernatant were subjected to SDS-PAGE on a vertical $12.5 \%$ or $10 \%$ polyacrylamide gel according to the method of Laemmli (1970), using the electrophoresis equipment model SE-280 (Hoefer Scientific Instruments, Pharmacia Biotech, San Francisco, Calif., U.S.A.).

\section{Results and Discussion}

\section{Physicochemical properties of flour}

Proximate composition and gluten content of In-, Mid-, and Out-flours are shown in Table 1. The results show that Mid- and Out-flours contained similar amounts of protein and gluten, but Out-flour had higher ash content than Midflour. In-flour contained the lowest amount of protein, gluten, and ash among the 3 flours. The higher content of dry gluten than protein of flour is attributed to the contamination of starches and fibers of hand-washed gluten. Table 2 displays the physical properties of the 3 flours measured by extensigraph and texture analyzer. These results indicate that In-flour had large resistance to extension $\left(\mathrm{R}_{5}\right.$ or $\left.\mathrm{R}_{\max }\right)$, low extensibility (E), and high R/E values. Although Mid- and Out-flours contain a similar amount of protein (Table 1), Out-flour dough was more extensible and less resistant to extension than Mid-flour when measured by extensigraph. This may be due to Out-flour containing more damaged starch, nonstarch polysaccharide, and enzymes that are usually higher in or near the aleurone layer region than the central section of a wheat kernel (MacMasters and others 1971). Substances such as damaged starch or nonstarch polysaccharides may result in potentially high water absorption that 
Table 2-Physical properties of In-, Mid- and Out-flours'

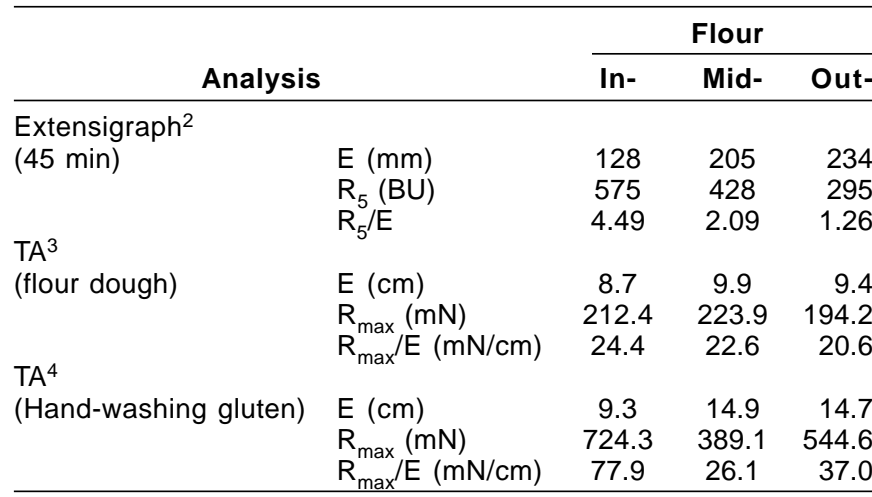

1 At least 15 replicates were done for TA measurements and the means were given. The $\mathrm{CV}$ of the measurements of $E, R_{\max }$ and $R_{\max } / E$ are less than 7,5 , and $7 \%$, respectively.

2 Data were provided by the flour mill.

3 Dough was prepared with $52 \%$ of water level.

4 Wet gluten was hand-washed from dough prepared in 3 .

results in a dough with large extensibility and low resistance to extension (Bushuk 1966; Mani and others 1992).

Both extensigraphy and texture analyzer have been used to measure the viscoelastic properties of flour dough, although the differences in order of $\mathrm{E}$ and $\mathrm{R}_{\max }$ data are observed in this study (Table 2). These are attributed to different equipment and parameters used to perform the measurements. However, both determinations can reveal clearly the differences in viscoelasticity of dough under the influence of material, additive, and processing (Chen and Hoseney 1995).

Viscoelasticity of wheat flour dough affected by water

Water absorption means the amount of liquid that is required to give a dough proper handling and machining properties that will produce the best final baked product (Pyler 1988). Optimal water content for preparing a dough is dependent on the wheat variety, milling performance, flour composition, formulation, processing methods, and baked product properties (Larsen and Greenwood 1991). Before investigating the effects of MTGase on the viscoelasticity of 3 different flours, the optimal water content for preparing the In-, Mid-, or Out-flour dough with suitable handling properties by using a KitchenAid desktop mixer should be determined. Figure 1 shows the results of the effects of water content on the viscoelasticity of wheat flour doughs. Although various water contents were used for dough preparation, the changes in viscoelasticity of the 3 flours under the influence of water content are similar. In general, $R_{\max }$ decreases with an increase in water absorption while $\mathrm{E}$ increases with an increase in water absorption. Adding water to dough results in a strong plasticizing effect and causes an extensible dough (Berland and Launay 1995). It is also found that small $\mathrm{E}$ values were obtained when excess water was applied. This is attributed to the excess water causing a soft and sticky dough, which significantly decreases the E values (Mani and others 1992; Gras and others 2000). Therefore, $\mathrm{R}_{\max } / \mathrm{E}$ decreases first with increase in water content but increases slightly with excess water.

\section{Viscoelasticity of wheat flour dough affected by MTGase}

Since MTGase has been reported to be capable of
Table 3-Effects of MTGase and vitamin C treatments on dough extensibility (E) and maximum resistance force to extension $\left(R_{\max }\right)$ of each kind of flour at specific water level ${ }^{1}$

\begin{tabular}{llccr}
\hline Flour $^{2}$ & Treatment & $\mathbf{E}(\mathbf{c m})$ & $\mathbf{R}_{\max }(\mathbf{m N})$ & $\begin{array}{r}\mathbf{R}_{\max } / \mathbf{E} \\
(\mathbf{m N} / \mathbf{c m})\end{array}$ \\
\hline In-(58\%) & None & $8.2 \mathrm{a}^{3}$ & $178.0 \mathrm{c}$ & $21.7 \mathrm{~d}$ \\
& 8 ppm MTGase & $7.7 \mathrm{~b}$ & $208.3 \mathrm{~b}$ & $27.4 \mathrm{c}$ \\
& 16 ppm MTGase & $7.4 \mathrm{~b}$ & $253.3 \mathrm{a}$ & $34.4 \mathrm{~b}$ \\
& 100 ppm L-ascorbic & $4.9 \mathrm{c}$ & $282.5 \mathrm{a}$ & $57.8 \mathrm{a}$ \\
& acid & & & \\
Mid-(56\%) & None & $10.0 \mathrm{a}$ & $207.0 \mathrm{c}$ & $20.8 \mathrm{c}$ \\
& 8 ppm MTGase & $9.8 \mathrm{ab}$ & $213.0 \mathrm{c}$ & $21.9 \mathrm{c}$ \\
& 16 ppm MTGase & $8.9 \mathrm{~b}$ & $279.4 \mathrm{~b}$ & $31.5 \mathrm{~b}$ \\
& 100 ppm L-ascorbic & $7.6 \mathrm{c}$ & $452.7 \mathrm{a}$ & $59.8 \mathrm{a}$ \\
& acid & & & \\
& None & $10.6 \mathrm{a}$ & $260.5 \mathrm{~b}$ & $25.0 \mathrm{~b}$ \\
& 8 ppm MTGase & $9.4 \mathrm{a}$ & $250.0 \mathrm{~b}$ & $27.2 \mathrm{~b}$ \\
Out-(50\%) & 16 ppm MTGase & $7.8 \mathrm{~b}$ & $493.2 \mathrm{a}$ & $63.4 \mathrm{a}$ \\
& None & $9.4 \mathrm{ab}$ & $194.2 \mathrm{c}$ & $20.9 \mathrm{~b}$ \\
Out-(52\%) & 8 ppm MTGase & $10.1 \mathrm{a}$ & $247.1 \mathrm{~b}$ & $24.9 \mathrm{~b}$ \\
& 16 ppm MTGase & $8.8 \mathrm{~b}$ & $343.2 \mathrm{a}$ & $39.3 \mathrm{a}$ \\
& 100 ppm L-ascorbic & $9.5 \mathrm{ab}$ & $359.4 \mathrm{a}$ & $38.7 \mathrm{a}$ \\
& acid & & & \\
\hline
\end{tabular}

1 At least 15 replicates were done for TA measurements and the means were given. The $\mathrm{CV}$ of the measurements of $E, R_{\max }$ and $R_{\max } / E$ are less than 7 ,

5 , and $7 \%$, respectively.

2 The percentage indicated in parentheses represents the water level of each flour in dough preparation to which the treatment was applied.

3 The mean values in the same column (within each flour at specific water level) with the different letters are significantly different $(p<0.05)$

strengthening the dough and increasing water absorption (Gerrard and others 1998, 2000), doughs prepared with high water contents, based on the results of Figure 1, are used to evaluate the effects of MTGase on improving the dough properties. The water levels for dough prepared with In- and Mid-flour were $58 \%$ and $56 \%$, respectively. For Out-flour, which especially needs to be improved, both $50 \%$ and $52 \%$ water levels were tested. The effect of MTGase on E and $R_{\max }$ of these 3 flours dough are shown in Table 3. Two levels of MTGase dosage (8 and $16 \mathrm{ppm}$ on flour basis) were tested and $100 \mathrm{ppm}$ L-ascorbic acid was also tested for comparison of the dough strengthening effects.

It is found that the effects of MTGase on the viscoelastic properties of dough depended on type of flour and dosage of MTGase. In In-flour, E decreased when it was treated with MTGase but the differences between 2 MTGase dosages were not significant. However, $\mathrm{R}_{\max }$ and $\mathrm{R}_{\max } / \mathrm{E}$ were significantly different between treated and nontreated flour doughs, and they increased with an increase in the dosage of MTGase. In Mid-flour, only a high dosage of MTGase (16 ppm) caused the decrease in $\mathrm{E}(\uparrow 11 \%)$ and increase in $\mathrm{R}_{\max }(\downarrow 35 \%)$ and $\mathrm{R}_{\max } / \mathrm{E}(\downarrow 51 \%)$ of dough significantly. In Out-flour, when the water content was $50 \%$, only 16 ppm MTGase treated dough had significant differences in $\mathrm{E}, \mathrm{R}_{\max }$ and $\mathrm{R}_{\max } / \mathrm{E}$ values from nontreated and $8 \mathrm{ppm}$ MTGase treated dough. In the dough with high water content (52\%), the addition of MTGase caused significant changes in the viscoelastic properties of both treated dosages. The different effects of water content on the MTGase treated doughs contributed to the combined effects of cross-linking of enzyme and the lubricant effect of water on the dough as excess water was applied. As the amount of water added into the flours increases, unbonded water (excess water) plays a lubricating role within the gluten-starch-lipid-bonded-water network and results in an increase in $\mathrm{E}$ values while the $\mathrm{R}_{\max }$ decreases (Gras and others 

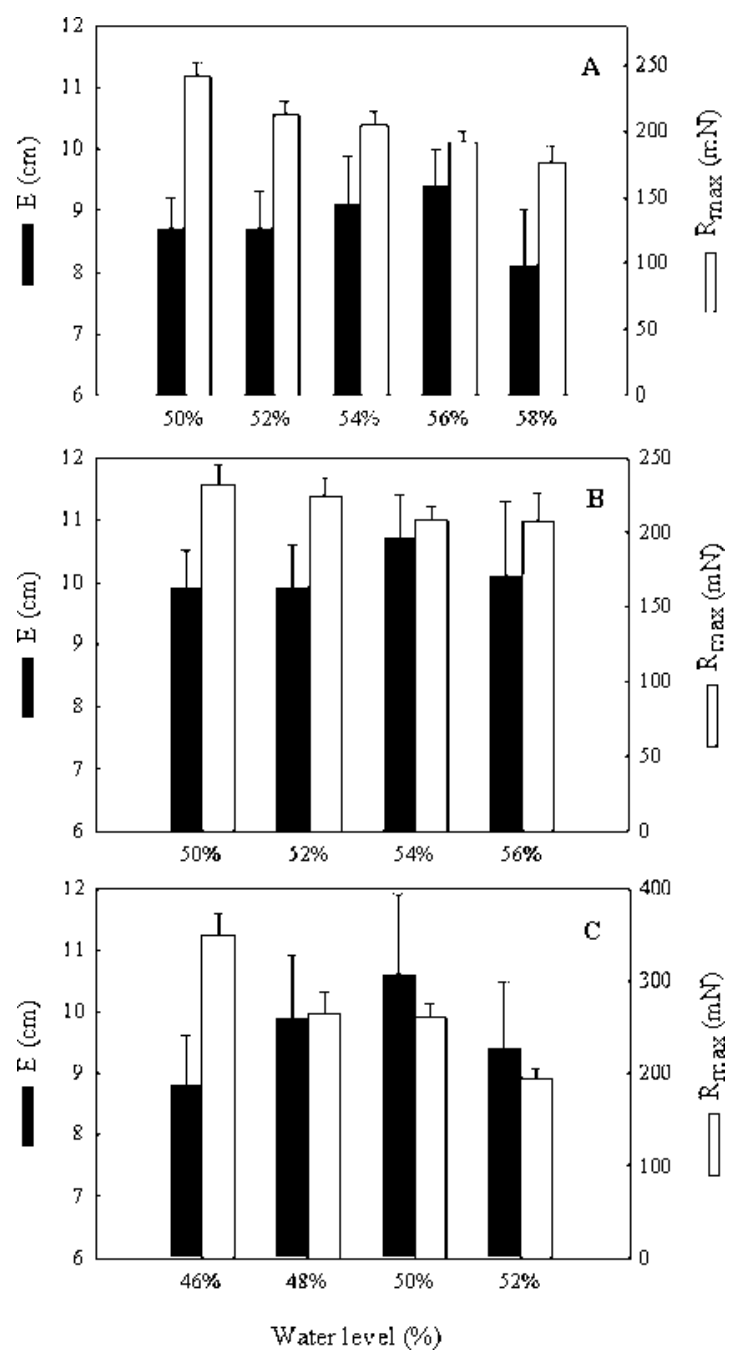

Figure 1-E and $R_{\text {}}$ values of (A) In-, (B) Mid-, and (C) Outflour dough prepared with various water levels. The error bars represent the standard deviation of each group.

2000). At the same time, the unbonded water provides the environment for carrying out the cross-linking reactions of MTGase between proteins. Therefore, a small amount of enzyme (8 ppm) is ready to show significant influence on the changes of viscoelastic properties of dough when excess water is used for dough preparation.

The viscoelastic properties of doughs treated with 100 ppm L-ascorbic acid were also investigated in this study for comparison. In In-flour, a decrease in $\mathrm{E}(\uparrow 44 \%)$ and an increase of $R_{\max }(\downarrow 68 \%)$ are observed when treated with 100 ppm L-ascorbic acid. A short or bucky dough with a high $\mathrm{R}_{\max } / \mathrm{E}$ value $(58 \mathrm{mN} / \mathrm{cm})$ was obtained. Similar effects are also observed in the treated Mid-flour dough, for which which a decrease in $\mathrm{E}(\uparrow 24 \%)$ and an increase of $\mathrm{R}_{\max }$ $(\downarrow 118 \%)$ are observed. When Out-flour dough prepared with $52 \%$ water content was treated with $100 \mathrm{ppm} \mathrm{L-ascorbic}$ acid, the $E, R$, and $R_{\max } / E$ values were similar to those values measured from the dough treated with 16 ppm MTGase.

Although both MTGase and L-ascorbic acid can be used as flour improvers with a function of dough strengthener by
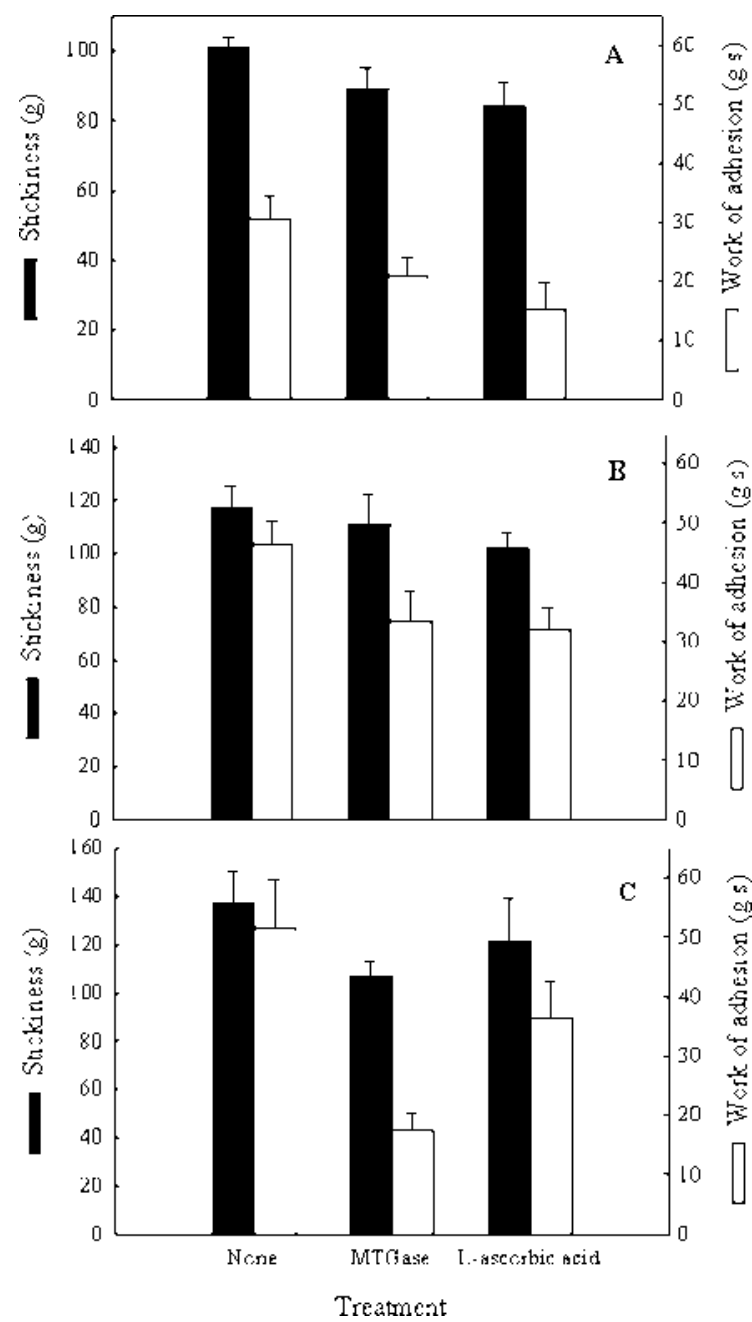

Figure 2-Stickiness and work of adhesion of doughs prepared with (A) In-(58\%), (B) Mid-(56\%), and (C) Outflour(52\%), at specific water level indicated in parentheses. The dosages of MTGase and L-ascorbic acid used for dough preparation are 16 and $100 \mathrm{ppm}$, respectively. The error bars represent the standard deviation of each group.

the formation of covalent intra- or inter-molecular bonds between proteins, different effects of both additives on the viscoelastic properties of dough are expected. L-ascorbic acid has been believed to act as an intermediary in the oxidation processes in dough. It is first to be oxidized to dehydrogen ascorbic acid (DHAA), which then reacts with thiols to form disulfide and finally regenerate it into ascorbic acid (Stauffer 1990). Although L-ascorbic acid has strengthening effects, the dough structure is little modified by treating with 40 ppm L-ascorbic acid (Berland and Launay 1995). The strengthening effect of MTGase on dough is attributed to the formation of G-L bond of gluten (Ashikawa and others 1990; Gerrard and others 1998). The reaction rates of enzymes involved for the formation of intermolecular covalent bonds and the number of cross-link bond formation may be different in both MTGase and L-ascorbic acid treated doughs. As a result, they will contribute to the different effects on the 


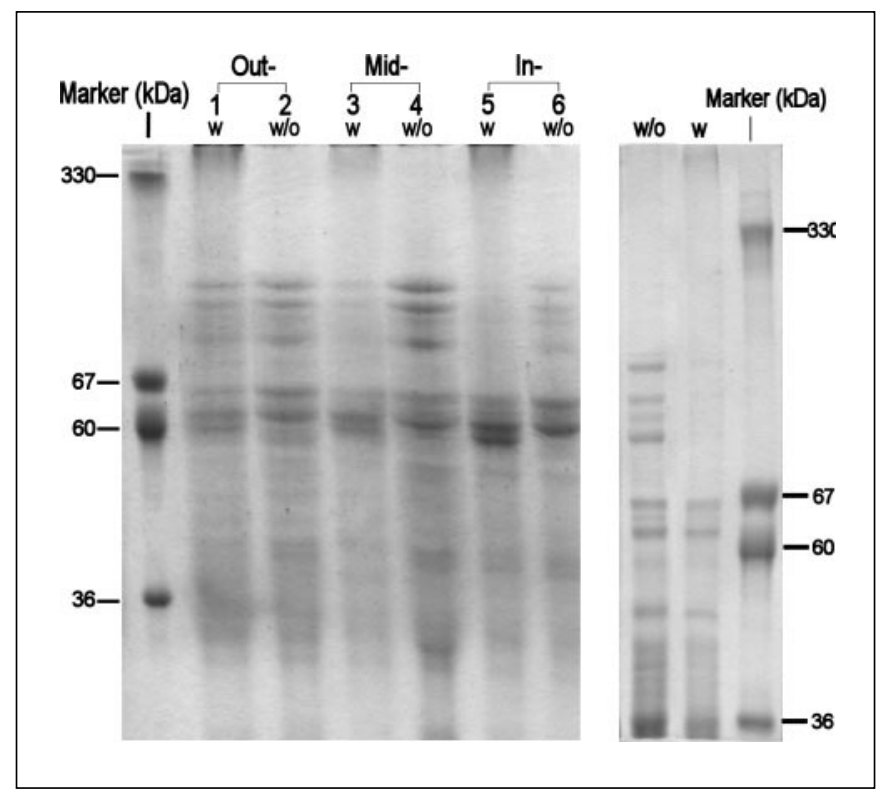

Figure 3-SDS-PAGE of hand-washed glutens with or without MTGase treatment. The dosage of MTGase applied is $40 \mathrm{ppm}$. Glutens were incubated in $0.1 \mathrm{M}$ Tris-HCI (pH 7.5) at $37^{\circ} \mathrm{C}$. The ' $w$ ' and ' $w / 0^{\prime}$ ' represent 'with' and 'without' MTGase treatment, respectively. (A) Comparison of In-, Mid-, and Out-flour glutens, incubated for $18 \mathrm{~h}$. Acrylamide concentration: $12.5 \%$, electrophoresis condition: 160V. (B) Out-flour gluten, incubated for $20 \mathrm{~h}$. Acrylamide concentration: $10 \%$, electrophoresis condition: $130 \mathrm{~V}$.

dough properties when MTGase or L-ascorbic acid is used to modify the properties of flour doughs.

\section{Stickiness of wheat flour dough affected by MTGase}

Stickiness is also an important factor that affects handling convenience in dough processing. The sticky dough, which causes damage to machinery, would be troublesome. Figure 2 shows the effects of MTGase (16 ppm on flour basis) on the reduction in dough stickiness, and lowering effect of the work of adhesion on 3 wheat flour doughs prepared with high water absorption. The results indicate that $16 \mathrm{ppm}$ MTGase decreased the stickiness by $12 \%, 5 \%$ and $22 \%$, while 100 ppm L-ascorbic acid decreased the stickiness by $17 \%, 12 \%$, and $12 \%$ for In-, Mid-, and Out-flour, respectively. It clearly indicates that Out-flour reflects greater response to MTGase than L-ascorbic acid in reducing dough stickiness. Compared with the results of nontreated dough, the decreases in the work of adhesion of treated dough (MTGase or L-ascorbic acid) are significant $(p<0.05)$. The reduction in dough stickiness and lowering effect of work of adhesion on the treated dough indicate that more water is allowed to be added into dough when it is treated with MTGase. Gerrard and others (1998) indicate that addition of another $6 \%$ of water to the dough with $5000 \mathrm{ppm}$ MTGase treated can still give a consistent dough feeling and maintain good baking quality. Although the reasons for the increased water absorption of the MTGase treated dough is not clear, altering the structure of the gluten matrix by crosslink may lead to better dough development and an increased capacity to hold water (Gerrard and others 1998). An alternative explanation is the results of side activity of MTGase. MTGase will hydrolyze glutamine residues to glutamic acid residues in protein as a result of the increase of hydrophilicity of the gluten and a higher affinity for water (Alexandre and others 1993).

\section{SDS-PAGE of gluten modified by MTGase}

In a previous study (Tseng 2001) it was found that the results of electrophoresis of gluten extracted from the 8 or 16 ppm MTGase treated flour doughs were not significant for further analysis. It is attributed that the reactions of MTGase and proteins were too mild to be detected at such reaction conditions (that is, low dosage of enzyme, short reaction time and so on). Therefore, pre-extracted gluten, high dosage of enzyme, and long reaction time were designed for the electrophoresis analyses to provide indirect evidence of the polymerization reactions that occurred when wheat flour was treated with MTGase.

As seen in lanes 1, 3 and 5 in Figure 3(A), MTGase-treated gluten, which was extracted from Out-, Mid-, and In-flour, respectively, show additional dark zones at the top of the gel. This indicates that large molecules formed when treated with MTGase so that the sizes of molecules are too large to go through the electrophoresis gel. In addition, significant reductions of band areas of molecular weight between 67 to $330 \mathrm{kDa}$ of treated wheat gluten sample (lanes 1, 3, and 5) are observed. Similar results have been reported by Larré and others (2000). This is attributed to the signs of G-L crosslink bonds. Various effects of degree of polymerization of MTGase on gluten, which derived from different flours, can also be observed from SDS-PAGE gel. Polymerization reaction of MTGase on the gluten was more complete after $18 \mathrm{~h}$ of incubation of In- and Mid-flour than Out-flour (Figure 3(A)). Molecules of 67 to $330 \mathrm{kDa}$ disappeared (Figure 3(B)) when MTGase-treated Out-flour gluten was incubated for a longer time $(20 \mathrm{~h})$, which suggests that Out-flour requires more time for the polymerization reactions to occur.

\section{Conclusion}

$\mathrm{M}$ ICROBIAL TRANSGLUTAMINASE HAS THE ABILITY TO MODIFY wheat protein effectively by forming $\varepsilon^{-}(\gamma-$ glutamyl)lysine bonds as a result of the modifications of some important physical properties of wheat flour dough, including stickiness, extensibility, and maximum resistance to extension. The treatment by MTGase is efficient at low content ( $8 \mathrm{ppm})$ for In-flour and at higher content (16 ppm) for Mid- and Out-flours. The different levels of response to MTGase is attributed to the different quality of proteins and the contribution of nonprotein components in Mid- and Outflours. Results of SDS-PAGE indicate that the modification of MTGase on the viscoelastic properties of the dough may be due to the polymerization effects of gluten. Compared to Lascorbic acid, which have been used as a dough improver for decades, MTGase has proved to be a potential enhancer of baking properties because a very small dosage can cause obvious modifications on dough properties. For the potential utilization of MTGase in the practice of baking, further tests are needed to examine its effects on flour quality, formulation, processing methods, and quality expectation of final products.

\section{References}

AACC. 1995. Approved Method of the American Association of Cereal Chemist, 9th ed. St. Paul, MN: AACC Inc.

Alexandre M-C, Popineau Y, Viroben G, Chiarello M, Leion A, Guegen J. 1993. Wheat $\gamma$-gliadin as a substrate for bovine plasma factor XII. J Agric Food Chem 41:2208-2214.

Ando H, Adachi M, Umeda K, Matsuura A, Nonaka M, Uchio R, Tanaka H, Motoki M. 1989. Purification and characteristics of a novel transglutaminase derived from microorganisms. Agric Biol Chem 53:2613-2617. 
Ashikawa N, Fukui H, Toiguchi S, Motoki M. 1990. Transglutaminase-containing wheat and premix for cake, and manufacture of cake using them. Japan Kokai Tokkyo Hoho. Japanese Patent: JP02286031.

Babiker EE, Hiroyuki A, Matsudomi N, Iwata H, Ogawa T, Bando N, Kato A. 1998. Effect of polysaccharide conjugation or transglutaminase treatment on the allergenicity and functional properties of soy protein. J Agric Food Chem 46:866-871.

Berland S, Launay B. 1995. Rheological properties of wheat flour doughs in steady and dynamic shear: effect of water content and some additives. Cereal Chem 72:48-52.

Bushuk, W. 1966. Distribution of water in dough and bread. The Bakers Digest 40:38.

Chakraborty K, Khan K. 1988. Biochemical and breadmaking properties of wheat protein components. I. Compositional differences revealed through quantitation and polyacrylamide gel electrophoresis of protein fractions from various isolation procedure. Cereal Chem 65:333-340.

Chen WZ, Hoseney RC. 1995. Development of an objective method for dough stickiness. Lebensm-Wiss Technol 28:467-473.

Dube R, Indrani D, Leelavathi K, Sidhu JS. 1987. Flour millstreams I. Physicochemical and rehological characteristics. Indian Millers 1:17-34.

Færgemand M, Qvist KB. 1997. Transglutaminase: effect on rheological properties, microstructure and permeability of set style acid skim milk gel. Food Hydrocoll 11:287-292.

Færgemand M, Otte J, Qvist KB. 1997. Enzymatic cross-linking of whey proteins by a $\mathrm{Ca}^{+2}$-independent microbial transglutaminase from Streptomyces lydicu. Food Hydrocoll 11:19-25.

Færgemand M, Otte J, Qvist KB. 1998. Emulsifying properties of milk protein cross-linked with microbial transglutaminase. Int Dairy J 8:715-723.

Folk JE, Cole PW. 1966. Transglutaminase: mechanistic features of the active site as determined by kinetic and inhibitor studies. Biochim Biophys Acta 122:244264.

Gerrard JA, Fayle SE, Wilson AJ, Newberry MP, Ross M, Kavale S. 1998. Dough properties and crumb strength of white pan bread as affected by microbial transglutaminase. J Food Sci 63:472-475.

Gerrard JA, Newberry MP, Ross M, Wilson AJ, Fayle SE, Kavale S. 2000. Pastry lift and croissant volume as affected by microbial transglutaminase. J Food Sci 65:312-314.

Gras PW, Carpenter HC, Anderssen RS. 2000. Modeling the developmental rheology of wheat flour dough using extension tests. J. Cereal Sci 31:1-13.

Imm JY, Lian P, Lee CM. 2000. Gelation and water binding properties of transglutaminase-treated skim milk powder. J Food Sci 65:200-205.

Jensen SA, Martens H. 1983. The botanical constituents of wheat and wheat milling fractions. II. Quantification by amino acids. Cereal Chem 60:172-177.

Jones CR, Halton P, Stevens DJ. 1959. The separation of flour into fractions of different protein contents by means of air classification. J Biochem Microbiol Technol Eng 1:17.

Kieffer R, Stein N. 1999. Demixing in wheat doughs-Its influence on dough and gluten rheology. Cereal Chem 76:688-693.

Kuraishi C, Sakamoto J, Yamazaki K, Susa Y, Kuhara C, Soeda T. 1997. Production of restructured meat using microbial transglutaminase without salt or cooking. J Food Sci 62:488-515.

Laemmli UK.1970. Cleavage of structural proteins during the assembly of the head of bacteriophage T4. Nature 42:155-157.
Larré C, Denery-papini S, Popineau Y, Deshayes G, Desserme C, Lefebvre J. 2000. Biochemical analysis and rheological properties of gluten modified by transglutaminase. Cereal Chem 77:121-127.

Larsen NG, Greenwood DR. 1990. Water addition and the physical properties of mechanical dough development doughs and breads. J Cereal Sci 13:195-201. MacMasters MM, Hinton JJC, Bradbury D. 1971. Microscopic structure and composition of wheat kernel. In: Pomeranz Y, editor. Wheat chemistry and technology. Vol. 2. St. Paul, MN: AACC, Inc. p 51-113.

Mani K, Tragardh C, Eliasson AC, Lindahl L. 1992. Water content, water soluble fraction, and mixing affect fundamental rheological properties of wheat flour doughs. J Food Sci 57:1198-1200, 1209.

Posner ES, Hibbs AN. 1997. Wheat: the raw material. Chapter 1. In: Wheat flour milling. St. Paul, MN: AACC, Inc. U.S.A.

Prabhasankar P, Sudha P, Rao PH. 2000. Quality characteristics of wheat flour milled streams. Food Research Internal 33:381-386.

Pyler EJ. 1988. Wheat and wheat flour. In: Baking Science and Technology. 3rd ed ch. 7. Merriam, KS: Sosland Publishing Co. p 300-377.

Sakamoto H, Yamazaki K, Kaga C, Yamamoto Y, Ito R, Kurosawa Y. 1996. Strength enhancement by addition of microbial transglutaminase during Chinese noodle processing. Nippon Shokuhin Kagaku Kogaku Kaishi 43:598-602.

Sakamoto H, Kumazawa Y, Motoki M. 1994. Strength of gel prepared with microbial transglutaminase as related to reaction condition. J Food Sci 57:12141218 .

Seguro K, Nio N, Motoki M. 1996. Some characteristics of a microbial protein cross-linking enzyme: transglutaminase. In: Parris N, Kato A, Creamer LK, and Pearce J, editors. Macromolecular interactions in food technology Washington DC: American Chemical Society. p 271-280.

Singh H. 1991. Modification of food proteins by covalent crosslinking. Trends Food Sci Technol 8:196-200.

Soeda T, Yamazaki K, Sakaguchi S, inventors; Strehl Schubel-Hopf \& Partner, representative. 1999. Dec 15, 1999. Food containing proteinaceous material treated with transglutaminase and an oxidoreductase. European Patent EP 0963 704 A2.

Sproessler BG. 1993. Milling and baking. In: Nagodawithana T, Reed G, editors. Enzymes in food processing. ch. 11. New York: Academic Press, Inc. p 293-320. Stauffer CE. 1990. Oxidants. In: Stauffer CE, editor. Functional additives for bakery foods. New York: Van Nostrand Reinhold. p 1-40.

Tseng, CS. 2001. Effects of microbial transglutaminase on modifying the physicochemical properties of flour dough and its application in baking. [MSc The sis]. Taipei, Taiwan: National Taiwan Univ. Available from Library of National Taiwan Univ. (Code: (T)439.25.8066).

Wantanabe M, Suzuki T, Ikezawa Z, Arai S. 1994. Controlled enzymatic treatmen of wheat proteins for production of hypoallergenic flour. Biosci Biotech Biochem 58:388-390.

MS 20010108 Submitted 3/5/01, Accepted 12/27/01, Received 1/8/02

The authors would like to thank Mr. C.C. Chen in Chia Faa flourmill for helpful assistance of flour collection and measurements of extensigraph of flours.

Authors Tseng and Lai are with the Dept. of Agricultural Chemistry, National Taiwan Univ. Direct correspondence to author Lai (E-mail: hmlai@ccms.ntu.edu.tw). 